Tersedia online di: http://ejournal-balitbang.kkp.go.id/index.php/bawal
e-mail:bawal.puslitbangkan@gmail.com
BAWAL wIDYA RISET PERIKANAN TANGKAP
Volume 11 Nomor 2 Agustus 2019
p-ISSN: 1907-8226
e-ISSN: 2502-6410
BAWAWAL
Nomor Akreditasi Kementerian RISTEKDIKTI: 21/E/KPT/2018

\title{
SEBARAN DAN KEPADATAN MEGABENTOS DI PERAIRAN PULAU BUTON, SULAWESI TENGGARA
}

\section{DISTRIBUTION AND ABUNDANCE OF MEGABENTHOS IN BUTON ISLAND WATERS, SOUTHEAST SULAWESI}

\author{
Hendrik A.W. Cappenberg*1 ${ }^{* 1}$ Ran Ralph Thomas Mahulette ${ }^{2}$ \\ ${ }^{1}$ Pusat Penelitian Oseanografi-LIPI, Jl. Pasir Putih II, Ancol Timur Jakarta Utara, 14430, Indonesia \\ 2Pusat Riset Perikanan, Gedung BRSDM KP II, Jl. Pasir Putih II, Ancol Timur Jakarta Utara, 14430, Indonesia \\ Teregistrasi I tanggal: 07 Agustus 2018; Diterima setelah perbaikan tanggal: 19 Desember 2019; \\ Disetujui terbit tanggal: 27 Desember 2019
}

\begin{abstract}
ABSTRAK
Perairan Pulau Buton dan sekitarnya dengan wilayah terumbu karang yang cukup luas, kaya keanekaragaman hayati laut dan nilai estetika yang tinggi. Terumbu karang bermanfaat banyak bagi manusia dalam berbagai aspek ekonomi, sosial, dan budaya. Penelitian megabentos pada ekosistem terumbu karang ini telah dilakukan pada 2016 (April), 2017 (Juni) dan 2018 (Mei). Pengamatan dilakukan pada 15 stasiun yang tersebar pada pulaupulau besar dan kecil dari timur hingga barat. Tujuan penelitian ini untuk mengetahui sebaran dan kepadatan megabentos serta kemiripan spesies antar stasiun pada perairan tersebut. Pengambilan data dilakukan dengan menggunakan metode ReefCheck Benthos (RCB). Hasil pengamatan menunjukkan ada delapan spesies megabentos, diantaranya Drupella cornus menyebar secara luas (100\%), dan memiliki nilai total kelimpahan individu tertinggi, berkisar antara 35,7 - 57,9\%, (472 - 704 individu). Sedangkan Acanthaster planci memiliki sebaran yang terbatas dengan kelimpahan individu yang rendah $(0,3-1,0 \%)$. Kepadatan individu megabentos pada pengamatan April berkisar antara $0,16-2,31$ individu $/ 140 \mathrm{~m}^{2}$, pada Juni berkisar antara $0,11-1,47$ individu $/ 140 \mathrm{~m}^{2}$ dan 0,11 - 1,24 individu/140 $\mathrm{m}^{2}$ pada Mei. Dari tiga tahun pengamatan (2016 - 2018) kelimpahan rata-rata individu megabentos tidak ditemukan adanya perbedaan yang signifikan. Hasil analisa klaster menunjukkan bahwa kehadiran setiap spesies megabentos antar stasiun pengamatan dipengaruhi oleh kemiripan tipe substrat dan habitat.
\end{abstract}

Kata Kunci: Megabentos; sebaran dan kepadatan; Pulau Buton

\section{ABSTRACT}

The waters of Buton Island and its surrounding, has a large coral reef area with high species biodiversity and has an aesthetics value and beneficial for human being in many aspects such as economics, social and culture. Researches on megabenthos in coral reef ecosystems have been conducted in 2016 (April), 2017 (June) and 2018 (May) at 15 stations around large and small islands scattered from east to west. The aims of this study were to know the distribution and abundance of megabenthos and similarity of species between stations in these waters. Data collection is conducted using the Reef Check Benthos (RCB) method. The results shows that eight megabenthos was found, where Drupella cornus has a wide distribution (100\%), and has the highest total value of individual abundance, ranging from 35.7 - 57.9\%, (472 - 704 individuals). Whereas Acanthaster planci has a limited distribution with a low abundance of individuals $(0.3-1.0 \%)$. The abundance of megabenthos in April's observations ranged from $0.16-2.31$ individuals $/ 140 \mathrm{~m} 2$, in June it ranged from $0.11-1.47$ individuals/ $140 \mathrm{~m} 2$ and $0.11-1.24$ individuals/140m2 in May. In three years of observation (2016 - 2018) the average abundance of megabenthos individuals is not significantly different. The results of cluster analysis showed that the similarity of megabenthos species between observation stations was influenced by similarities in substrate type and habitat.

Keywords: Megabenthos; distribution and abundance; Buton Island 


\section{PENDAHULUAN}

Pulau Buton dan pulau-pulau kecil yang ada di sekitarnya terletak di Provinsi Sulawesi Tenggara, dan secara geografis berada pada posisi $4,96^{\circ}-6,25^{\circ}$ Lintang Selatan dan membentang dari barat ke timur di antara $120,00^{\circ}-123,34^{\circ}$ Bujur Timur. Wilayah perairan Buton merupakan salah satu dari banyak daerah di Indonesia yang kaya sumber perikanan, terumbu karang yang cukup luas, dengan nilai estetika yang tinggi dan memiliki banyak manfaat bagi manusia dalam berbagai aspek ekonomi, sosial, dan budaya.

Sebagai bagian dari wilayah ecoregion dunia, perairan Pulau Buton mencakup hamparan terumbu karang yang cukup luas dengan keanekaragaman jenis biota yang tinggi, termasuk megabentos. Megabentos merupakan kelompok organisme yang mendiami dasar perairan dan tinggal di dalam atau pada substrat serta memiliki pergerakan yang sangat lambat. Megabentos termasuk dalam kelompok polikhaeta, krustasea, ekhinodermata dan moluska, yang kehadirannya pada daerah terumbu karang dipengaruhi oleh karakter, tipe dan zonasi substrat. Sebaran dan kompleksitas habitat terumbu karang berpengaruh terhadap kelimpahan dan keanekaragaman spesies megabentos (Arthur, 1972). Berdasarkan sifat hidupnya megabentos ada yang menempel (sessil) pada substrat dan ada yang bergerak bebas. Megabentos mempunyai peranan penting dalam proses rantai makanan dan ekologi seperti menjadi pemangsa dan mangsa.

Kelompok megabentos yang mudah dijumpai pada terumbu karang diantaranya adalah genus Diadema yang bersifat herbivora dari kelas ekhinodermata. Secara ekologis, ekhinodermata berperan penting dalam ekosistem terumbu karang, terutama dalam rantai makanan (food chain) (Birkeland, 1989), dengan sumber makanan utamanya berupa alge (Aziz, 1981). Kehadiran Diadema pada ekosistem terumbu karang dengan jumlah individu yang cukup dapat mengontrol pertumbuhan alge (Nybakken, 1992), sehingga planula karang dapat menempel dan tumbuh. Sama halnya dengan genus Diadema, kehadiran Drupella dan Acanthaster pada ekosistem terumbu karang erat kaitannya dengan ketersedian makanan, namum bila terjadi ledakan populasi (outbreak) pada kedua spesies tersebut, dapat menyebabkan kerusakan pada karang. Sedangkan kehadiran spesies megabentos yang memiliki nilai ekonomis penting seperti teripang (Holothurian), lobster (Panulirus spp.), kima (Tridacna spp.), dan lola (Trochus spp.) semakin sulit ditemukan.

Berkurangnya populasi individu dari spesies-spesies tersebut bukan oleh rusak atau tidaknya terumbu karang, tetapi lebih disebabkan tingginya pemanfaatan spesies tersebut sebagai akibat dari meningkatnya permintaan pasar. Perburuan fauna ekonomis penting oleh masyarakat pesisir telah dilakukan sejak dahulu, karena secara ekonomis dapat dijadikan sebagai sumber mata pencaharian bagi masyarakat nelayan. Selain dagingnya dapat dikonsumsi sebagai sumber protein dan makanan kesehatan lainnya, cangkang lola, kima maupun lobster dapat digunakan sebagai bahan dasar untuk membuat souvenir. Cangkang lola sendiri, dapat digunakan sebagai bahan pembuatan kancing baju dan perhiasan berkualitas, sehingga permintaan ekspor cangkang lola terus meningkat untuk pasar Eropa, Taiwan dan beberapa negara Asia Timur lainnya (Edward, 2010). Seperti halnya dengan lola, Calumpong (1992) melaporkan bahwa daging otot adduktor dan mantel kima menjadi komoditas bernilai ekonomis tinggi, bahkan di Jepang, Taiwan, Hongkong, Selandia Baru, Australia, dan Amerika Serikat, kima merupakan makanan mewah. Meningkatnya pemintaan lobster dan teripang di pasar domestik maupun internasional dengan harga tinggi (Setyono, 2006; Hartati et al., 2005), memberi tekanan yang besar bagi ketersediaan populasinya di alam.

Tingginya eksploitasi biota tersebut menyebabkan populasi spesies-spesies tersebut terus menurun dan terancam punah. Oleh karena itu pemerintah telah mengambil tindakan konservasi dengan memasukan spesies-spesies tersebut sebagai satwa liar yang dilindungi sebagaimana diatur dalam Peraturan Pemerintah No.7 Tahun 1999. Penelitian fauna megabentos seperti ekhinodermata, krustasea dan moluska di terumbu karang perairan Pulau Buton dan pulau-pulau kecil lainnya belum banyak dilakukan, sehingga informasi keragaman dan kepadatannya masih relatif sedikit. Berdasarkan hal tersebut maka tujuan penelitian ini adalah untuk mengetahui sebaran dan kepadatan spesies megabentos di terumbu karang perairan Pulau Buton. Diharapkan hasil penelitian ini dapat memberikan tambahan informasi tentang keberadaan spesies megabentos di kawasan ekosistem tersebut dan dapat menjadi data dasar bagi pengamatan selanjutnya.

\section{BAHANDANMETODE}

Penelitian dilakukan pada April (2016), Juni (2017), dan Mei (2018) pada 15 stasiun pengamatan yang tersebar di bagian selatan perairan Pulau Buton dan pulau-pulau kecil lainnya (Gambar 1). Fauna megabentos yang diamati dalam penelitian ini terdiri dari berbagi kelompok seperti ekhinodermata, krustase, dan moluska, yang selama hidupnya hanya mendiami terumbu karang. Pengambilan contoh fauna megabentos dilakukan pada kedalaman 6 10 meter dengan menggunakan metode Reef Check Benthos (RCB) (Manuputty et al., 2006). Peralatan yang digunakan antara lain peralatan selam (SCUBA), alat tulis bawah air dan roll meter. Transek sepanjang 70 meter dibuat sejajar garis pantai (tubir), di atas terumbu karang 
(koloni karang) dengan jarak pengamatan 1 meter kiri dan kanan (lebar daerah pengamatan $2 \mathrm{~m}$ ), sehingga luas daerah pengamatan setiap titik-titik stasiun adalah $140 \mathrm{~m}^{2}(2 \times 70$ $\mathrm{m})$. Spesies-spesies megabentos yang ditemukan sepanjang meter/garis transek $(0-70)$ dicatat jumlah spesies dan jumlah individunya.

Identifikasi fauna megabentos dilakukan mengacu pada Abbott \& Dance (1990); Clark \& Rowe (1971); Dance (1976); Poutiers (1998); dan Wilson (1993). Untuk melihat ada tidak perbedaan rata-rata kelimpahan yang signifikan antar tahun pengamatan digunakan "One-Way Anova". Untuk mengetahui pengelompokan megabentos berdasarkan stasiun digunakan analisa indeks similaritas Bray-Curtis (Warwick \& Clarke, 2001). Hubungan antara kelimpahan setiap spesies megabentos dengan kehadiran spesies karang dianalisa menggunakan Generalised Linear Model. Analisa tersebut dilakukan dengan bantuan perangkat lunak R (R Core Development Team, 2018).

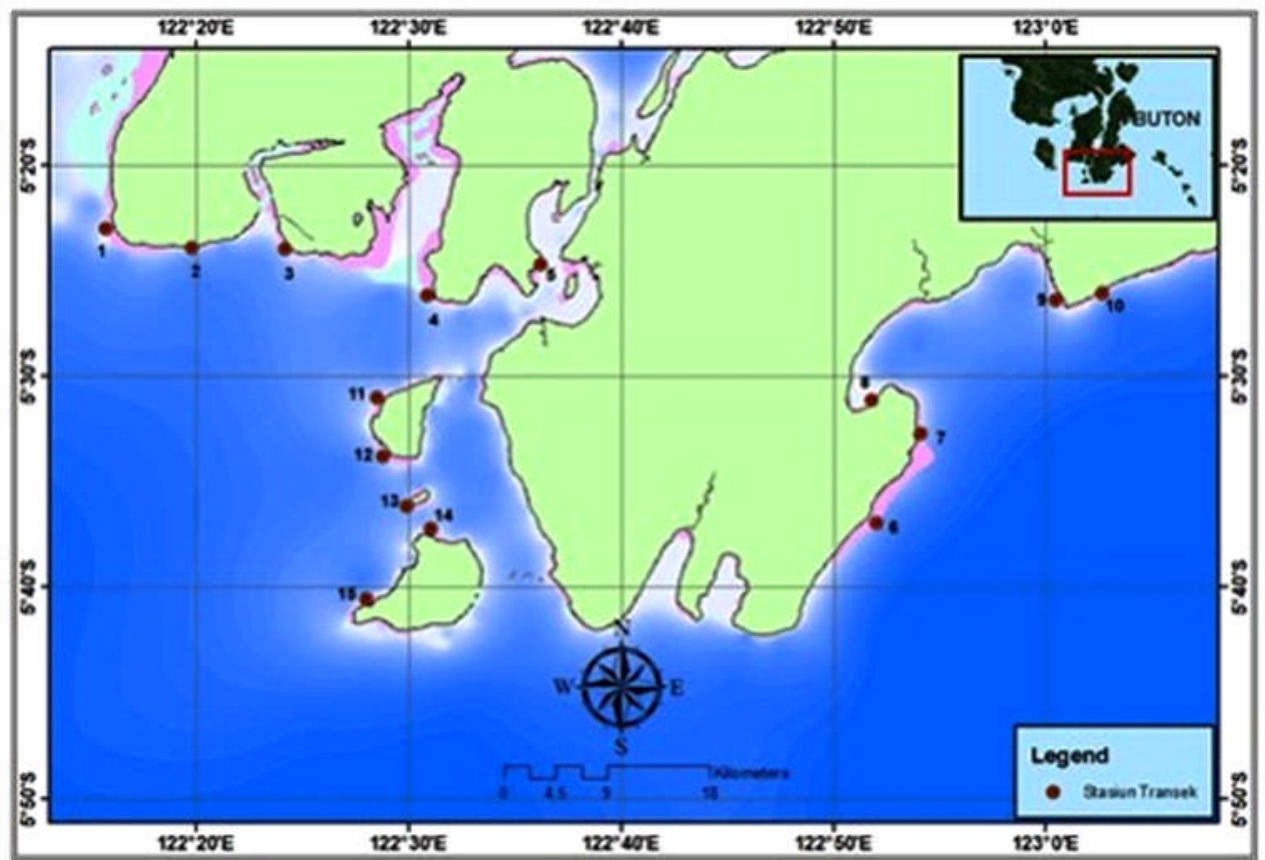

Gambar 1. Peta stasiun pengamatan megabentos di perairan Pulau Buton dan sekitarnya, Sulawesi Tenggara.

Figure 1. Map of megabenthos observation station in the waters of Buton Island and surrounding, Southeast Sulawesi.

\section{HASIL DAN BAHASAN \\ Hasil}

\section{Karakteristik Lokasi Penelitian}

Berdasarkan hasil pengamatan, terumbu karang di perairan Pulau Buton dan sekitarnya termasuk dalam tipe fringing reef dengan rataan terumbu yang sangat bervariasi, yang letaknya berkisar antara 200 - 700 meter dari tepi pantai. Pertumbuhan karang pada daerah pengamatan masih dapat dijumpai hingga kedalaman 20 meter. Topografi kemiringan lereng terumbu cukup bervariasi dan umumnya bertipe landai dengan kemiringin kurang dari $45^{\circ}$, terutama pada sasiun-stasiun yang berada di wilayah pantai Buton tengah dan sekitar Pasar Wajo Wabula. Bertipe agak curam $\left(>45^{\circ}\right)$, terdapat sekitar Buton Selatan Stasiun-stasiun yang berada di sebelah timur lebih terbuka, dan sering dilanda ombak besar, sehingga koloni karang yang tumbuh pada daerah ini didominasi oleh spesies-spesies karang massive seperti dari genus Porites.
Karang ini juga menyebar pada kisaran yang luas dengan laju pertumbuhan tinggi (Oportunistic) serta tahan terhadap tekanan lingkungan terutama terhadap perairan terbuka, salinitas rendah, panas, dan sedimentasi (Veron, 1993).

Hasil pengamatan menunjukkan bahwa persentase tutupan karang tidak sama pada setiap stasiun. Dimana karang yang dominan dan dijumpai pada semua stasiun pengamatan diwakili spesies-spesies yang termasuk dalam famili Acoporidae (78 spesies), Faviidae (66 spesies), Fungiidae (28 spesies), Pectinidae (14 spesies), Mussidae (13 spesies), Poritidae (12 spesies), Pocilloporidae (12 species), dan beberapa famili lain seperti Oculinidae, Siderasteridae, Merulinidae dan Helioporidae, hanya mencakup 1 - 9 spesies dengan persebaran yang terbatas (Anonimous, 2017). Secara umum, substrat yang ditemukan pada hampir semua stasiun pengamatan didominasi oleh substrat pasir, patahan karang mati (rubble) dan karang mati ditutupi alge (Dead coral with 
algae). Persentase tutupan karang hidup yang ditemukan pada stasiun pengamatan berada dalam kategori "sedang", yaitu 30,16\% (Anonimous, 2017c; Gomez \& Yap, 1988 ).

\section{Sebaran dan Kepadatan Megabentos}

Hasil pengamatan megabentos di perairan Kepulauan Buton, teridentifikasi sebanyak 8 spesies, yang tergolong dalam 3 kelompok, yaitu bintang laut berduri (Acanthaster planci), bulu babi hitam (Diadema setosum), bintang laut biru (Linckia laevigata), teripang (Holothurian), lobster (Panulirus sp.), Drupella cornus, kima (Tridacna spp.) dan lola (Trochus spp.). Spesies yang ditemukan di masingmasing stasiun cukup bervariasi, berkisar antara $2-7$ spesies. Dari semua spesies target megabentos yang ditemukan, kelompok ekhinodermata memiliki jumlah spesies terbanyak, (4 spesies) dan ditemukan pada semua tahun pengamatan (2016-2018), diikuti kelompok moluska (3 spesies). Jumlah spesies tertinggi pada pengamatan tahun 2016 terdapat di stasiun 10 (7 spesies), tahun 2017 terdapat di stasiun 1 dan 13 (masing-masing 7 spesies) dan tahun 2018 di stasiun 2, 4 dan 11 (masing-masing 6 spesies). Sedangkan spesies terendah di stasiun 9 (2016), stasiun 12 (2017) serta stasiun 9 dan 12 (2018), masingmasing 2 spesies (Tabel 1, Tabel 2 dan Tabel 3).

Sebanyak 3.670 individu megabentos berhasil ditemukan selama berlangsungnya pengamatan, dimana jumlah tersebut merupakan hasil pengamatan pada April (2016) sebesar 1.321 individu, Juni (2017) (1133 individu) dan Mei (2018) (1216 individu). Dari 15 stasiun yang diamati (2016 - 2018), hanya Drupella cornus memiliki sebaran yang luas, dengan nilai frekuensi kehadiran sebesar $100 \%$, diikuti Linckia laevigata dengan nilai frekuensi kehadiran berkisar antara 86,7\% - 93,3\% dan Diadema setosum (60\% - 86,7\%). Sedangkan Acanthaster planci, memiliki sebaran yang sangat terbatas, di mana besaran nilai frekuensi kehadiran $<30 \%$ Dari semua megabentos yang memiliki nilai ekonomis penting hanya lola, dengan sebaran yang cukup luas, sedangkan teripang, lobster, dan kima umumnya relatif terbatas (d" 60\%) (Tabel 1, Tabel 2 dan Tabel 3).

Kepadatan individu tertinggi pada pengamatan bulan April (2016) terdapat di stasiun 13, yaitu sebesar 2,31 individu/140m ${ }^{2}$ dan 6 spesies, diikuti stasiun $3(0,87$ individu $/ 140 \mathrm{~m}^{2}$ dan 6 spesies) dan yang terendah di stasiun 7 (0,16 individu/140 $\mathrm{m}^{2}$ dan 5 spesies). Pada pengamatan Juni (2017), individu tertinggi berada stasiun $13(1,47$ individu/ $140 \mathrm{~m}^{2}$ dan 7 spesies $)$ diikuti stasiun $4(1,07$ individu/ $140 \mathrm{~m}^{2}$ dan 6 spesies) dan terendah di stasiun 6 (0,11 individu/140 $\mathrm{m}^{2}$ dan 4 spesies). Sedangkan pada pengamatan Mei 2018, individu tertinggi juga berada di stasiun 13 (1,24 individu/140 $\mathrm{m}^{2}$ dan 5 spesies) dan terendah di stasiun 6 ( 0,11 individu $/ 140 \mathrm{~m}^{2}$ dan 3 spesies $)$.

Secara umum, nilai kepadatan fauna megabentos yang didapat selama tiga tahun pengamatan (2016-2018), cukup fluktuatif, dan peningkatan individu hanya terlihat pada stasiun 2, 5, 11 dan 15. Umumnya peningkatan ini dipengaruhi oleh kehadiran Drupella cornus dalam jumlah individu yang terus meningkat pada setiap tahun pengamatan. Sedangkan pada stasiun 4, 13 dan 14, kelimpahan individu megabentos cenderung menurun, yang disebabkan oleh menurunnya individu Diadema setosum dan Linckia laevigata dalam tiga tahun pengamatan. Pada stasiun 3 dan 9, fluktuasi nilai kepadatan individu dipengaruhi oleh Diadema setosum, Linckia laevigata dan Drupella cornus. Nilai kepadatan individu yang ditemukan selama tiga tahun pengamatan, menunjukkan Drupella cornus memiliki nilai total kelimpahan individu tertinggi, berkisar antara 35,7\% 57,9\%, (472 - 704 individu), Sedangkan Acanthaster planci memiliki kelimpahan individu yang rendah $(0,3 \%-1,0 \%)$. (Tabel 1, Tabel 2 dan Tabel 3). 


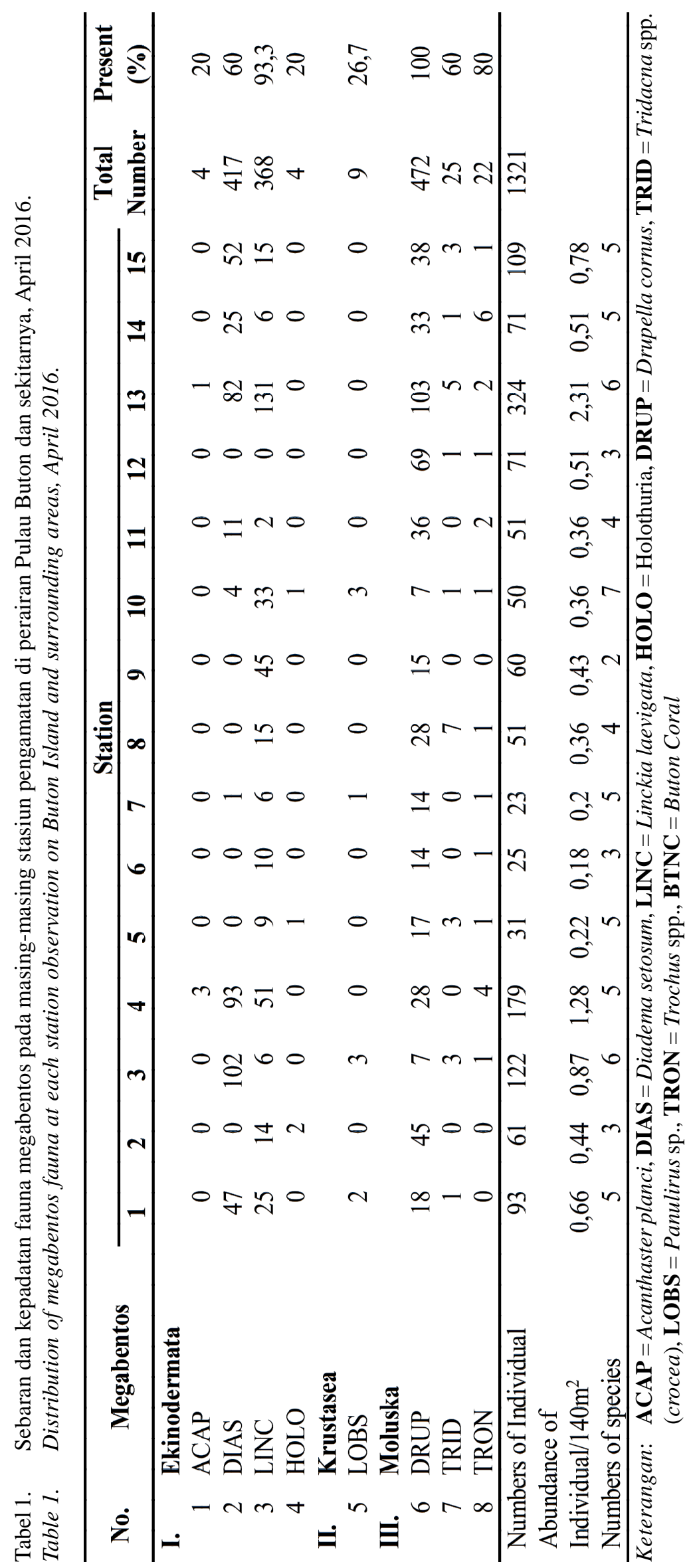




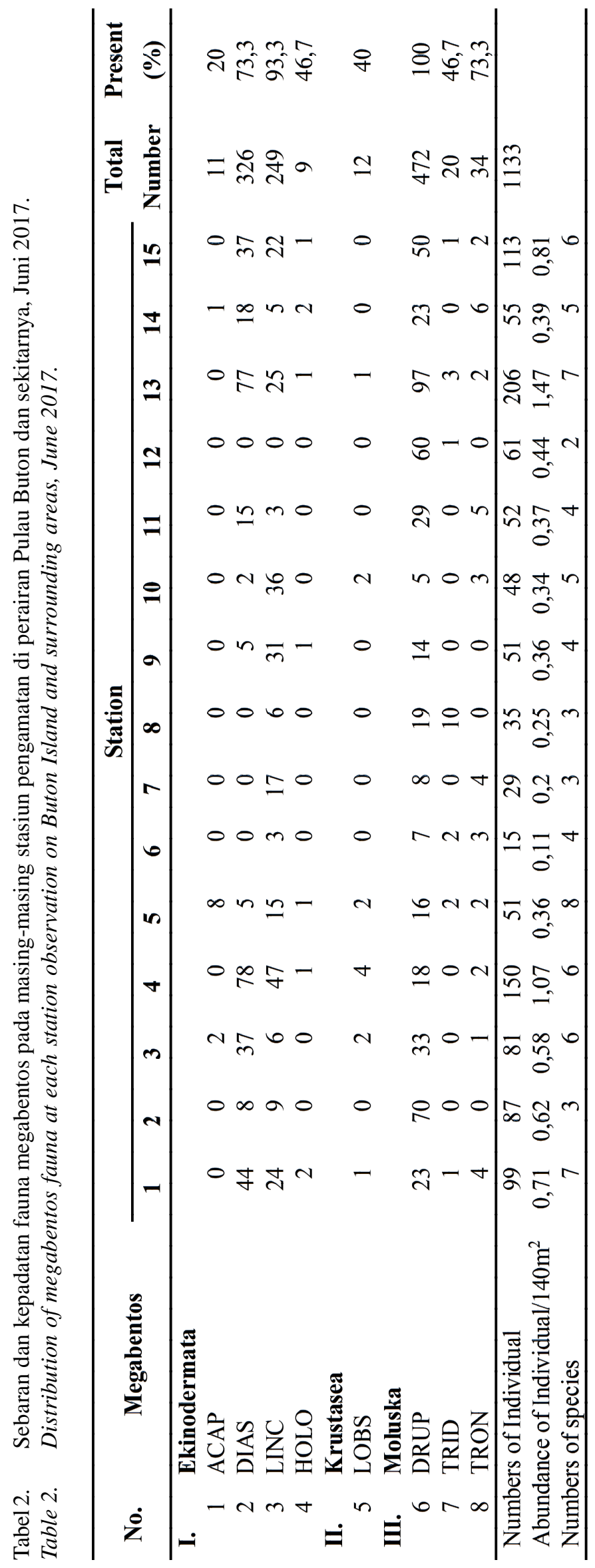




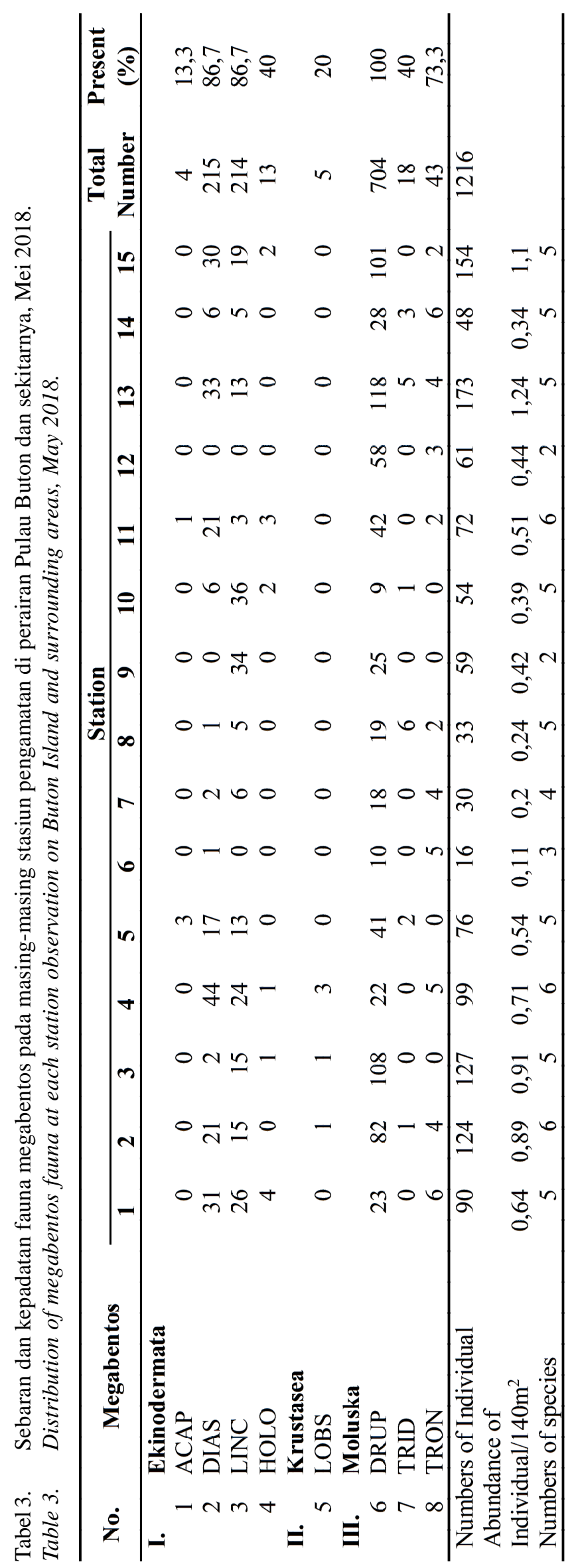


Jumlah spesies megabentos yang ditemukan dalam pengamatan ini (2018) tidak memperlihatkan perbedaan dengan pengamatan tahun sebelumnya (2016 dan 2017), mana semua spesies yang ditemukan pada setiap tahun pengamatan juga terdiri dari tiga kelompok utama dengan persebaran antar stasiun yang relatif sama. Fluktuasi kehadiran spesies megabentos yang cukup menonjol antar tahun pengamatan $(2016$ - 2018), hanya terlihat pada stasiun 2, 5, 11, 9 dan 8 yang dipengaruhi oleh hadirnya Acanthaster planci, Panulirus sp., Tridacna spp. dan Trochus spp. pada kedua tahun pengamatan sebelumnya (2016 dan 2017) (Gambar 2).

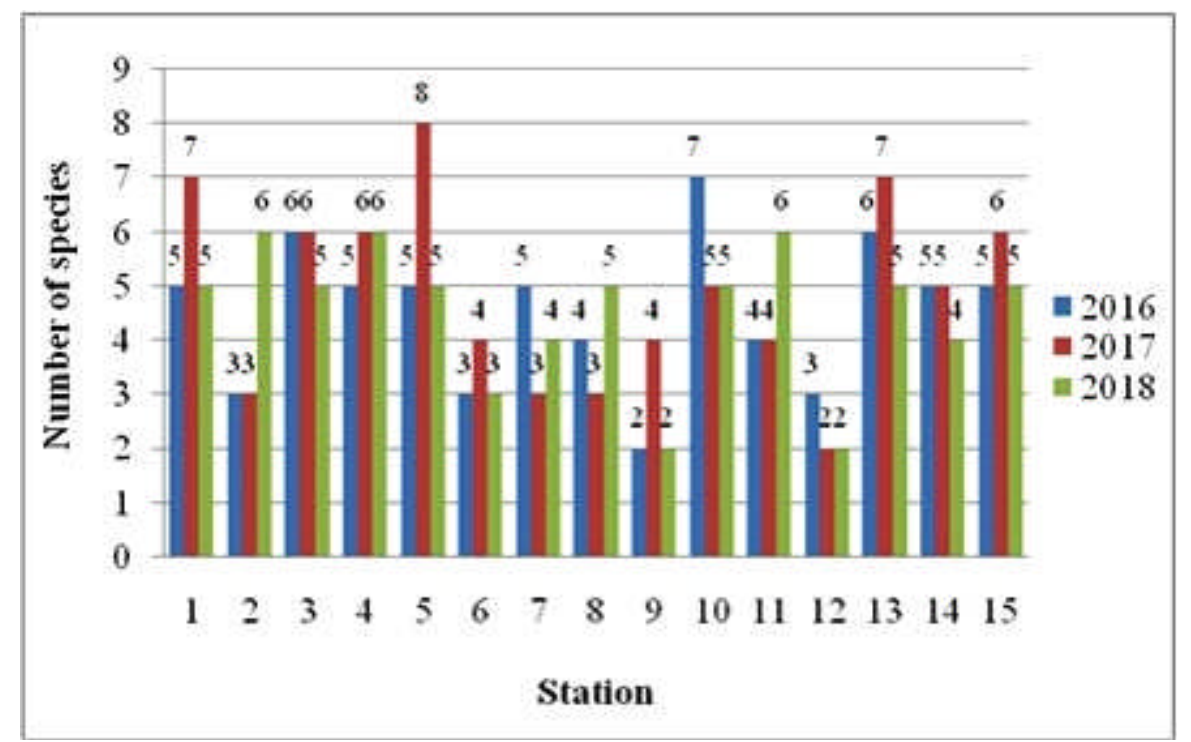

Gambar 2. Kehadiran spesis megabentos di setiap stasiun pada tahun pengamatan 2016 - 2018.

Figure 2. The presence of megabenthos spesies at each station in the year $2016-2018$ observations.

Walaupun ada terjadi kenaikan atau penurunan hasil analisis variasi kelimpahan rata-rata individu kepadatan individu pada spesies-spesies tertentu di setiap megabentos tidak memperlihatkan perbedaan yang signifikan stasiun pada masing-masing tahun pengamatan. Namun antara tahun pengamatan (2016-2018) (Gambar3).

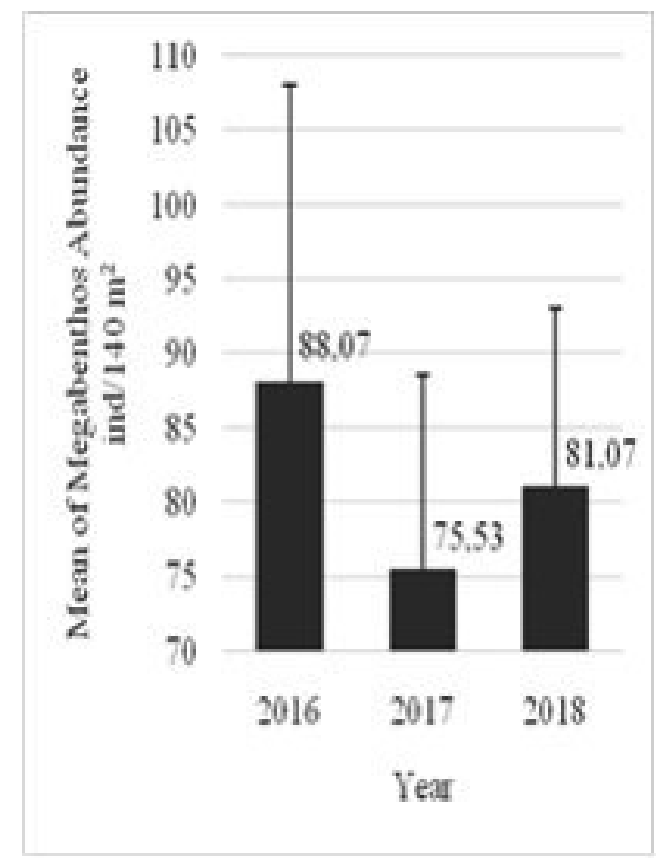

Gambar 3. Kepadatan rata-rata individu megabentos antara tahun pengamatan 2016-2018.

Figure 3. Abundance of the average individual megabenthos between years of observation $2016-2018$. 
Analisis kluster kemiripan (similarity) antar stasiun pada tiga tahun pengamatan (2016 - 2018 ) dilakukan dengan menggunakan data kepadatan individu megabentos yang ditemukan selama pengamatan. Nilai kemiripan tertinggi terdapat antara stasiun 11 dan 14 $(88,91 \%)$, yang dicirikan dengan kelimpahan spesies Drupella cornus dan Diadema setosum, diikuti stasiun 15 dan $3(86,04 \%)$ yang didominasi oleh Drupella cornus, Diadema setosum dan Linckia laevigata. Sedangkan nilai kemiripan sebesar 85,54\% tedapat antara stasiun 1 dan 4 yang dicirikan dengan dominannya individu Diadema setosum dan Linckia lavigata. Secara umum persebaran spesies megabentos antara stasiun pengamatan berada dalam nilai kemiripan yang tinggi, lebih besar dari $50 \%$ (Gambar 5).

Hasil analisa korelasi Spearman menggambarkan hubungan positif maupun negatif yang terjadi antara spesies-spesies megabentos dengan karang sebagai tempat hidupnya, , Semakin besar nilai korelasinya (mendekati 1), menunjukkan kuatnya hubungan antara megabentos dan spesies karang atau sebaliknya. Pada Gambar 4, terlihat bahwa nilai korelasi tertinggi berada antara Lobster (LOBS) dengan famili Mussidae dan Favidae (FA), diikuti Drupella cornus (DRUO) dengan Acroporidae (AC) serta Diadema setosum (DIAS) dengan Poritidae (PR).

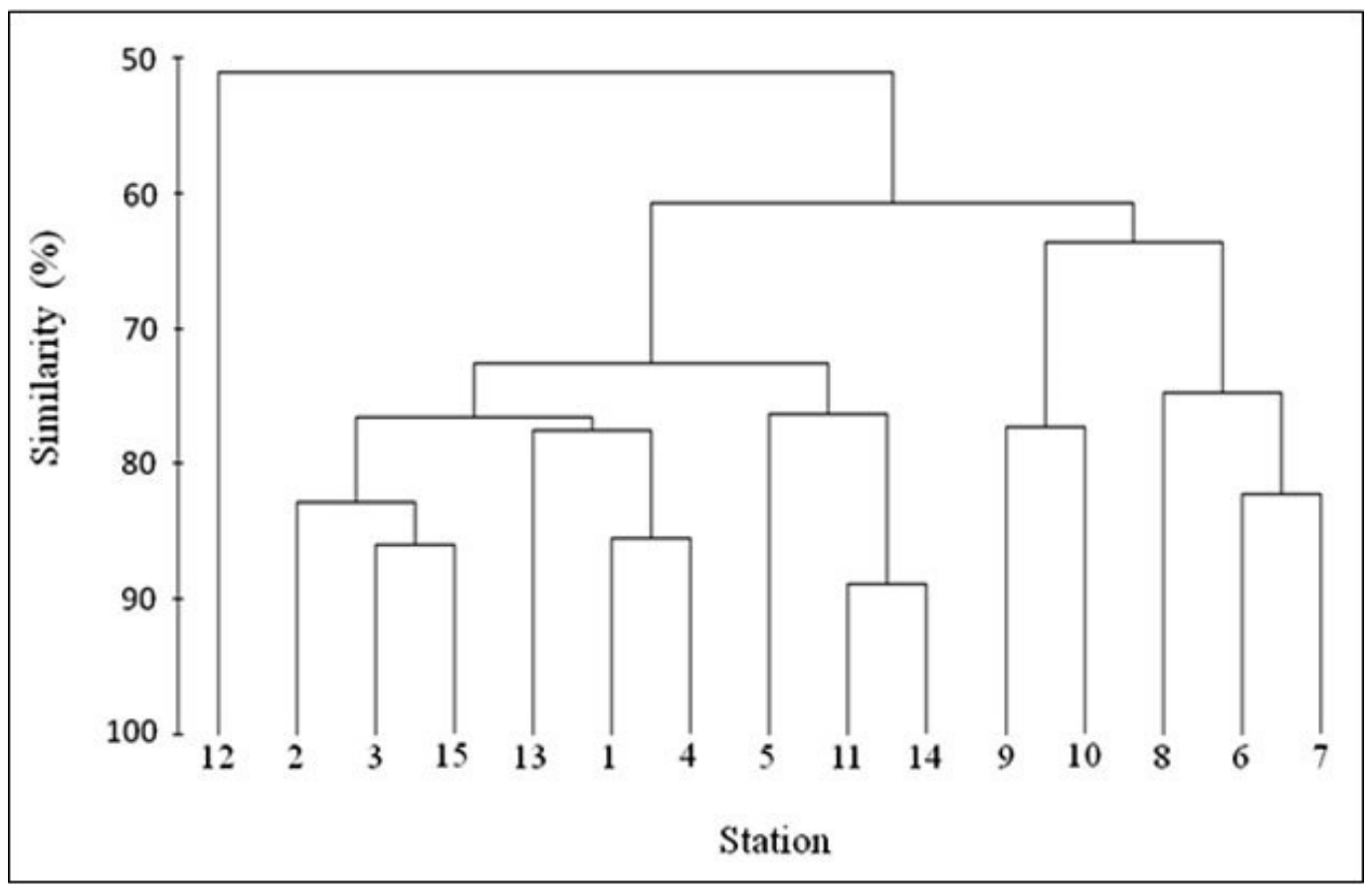

Gambar 4. Dendogram spesies megabentos di terumbu karang perairan Pulau Buton dan sekitarnya, Sulawesi Tenggara. Figure 4. Megabenthos species dendrogram on coral reefs of Buton Island and its surrounding waters, Southeast Sulawesi.

Tabei 4. Korelasi spearman antara spesies megabentos dan karang di perairan Pulau Buton dan sekitarnya Table 4. Spearman correlation rank between megabenthos and coral species in Buton Island and its surrounding waters

\begin{tabular}{ccccccc}
\hline \multirow{2}{*}{ Benthic Group } & \multicolumn{7}{c}{ Coral Group } \\
\cline { 2 - 7 } & $\mathbf{A C}$ & EU & FA & FU & MU & PR \\
\hline ACAP & 0,06 & 0,40 & $-0,10$ & $-0,08$ & $-0,12$ & $-0,20$ \\
DIAS & 0,28 & 0,21 & 0,22 & $0,41^{*}$ & 0,18 & $-0,58^{* *}$ \\
HOLO & 0,16 & 0,25 & $-0,16$ & 0,32 & 0,08 & $-0,23$ \\
LINC & $-0,05$ & $-0,04$ & 0,19 & 0,03 & $-0,09$ & $-0,14$ \\
LOBS & 0,15 & 0,09 & $0,50 *$ & 0,34 & $0,61^{* *}$ & 0,12 \\
DRUP & $0,57^{* *}$ & $0,43^{*}$ & 0,17 & 0,34 & 0,37 & $-0,03$ \\
TRID & $-0,13$ & $-0,15$ & $0,48^{*}$ & $-0,10$ & $-0,01$ & $-0,11$ \\
TRON & 0,02 & $-0,02$ & $-0,06$ & 0,21 & 0,10 & $-0,19$ \\
\hline
\end{tabular}

Keterangan $:$ ACAP = Acanthaster planci, DIAS = Diadema setosum, LINC = Linkia laevigata, HOLO = Holothuria, DRUP = Drupella cornus, TRID = Tridacna spp. (crocea), LOBS = Panulirus sp., TRON = Trochus spp.; AC = Acroporidae; $\mathbf{E U}=$ Euphylidae $; \mathbf{F A}=$ Faviidae $; \mathbf{F U}=$ Fungidae $; \mathbf{M U}=$ Mussidae $; \mathbf{P R}=$ Porotidae

$*$ = significantly correlated at 0.05 (alpha); ** = significantly correlated at 0.01 (alpha) 


\section{Bahasan}

Megabentos yang ditemukan pada terumbu karang dalam pengamatan ini umumnya beragam, sebanyak delapan spesies. Komposisi spesies ini sebanding dengan terumbu karang lainnya, di mana keragaman spesies megabentos dalam pengamatan ini relatif sama dengan hasil pengamatan Pramudji (2017) di perairan pesisir Teluk Kendari, Anonimous (2017) dalam penelitian di perairan Taman Nasional Kepulauan Wakatobi, dan di perairan terumbu karang perairan Kepulauan Ternate, serta Cappenberg (2014) dalam pengamatan di perairan Pankajene Kepulauan, Sulawesi Selatan yang masingmasing mendapatkan delapan spesies, dan lebih tinggi dibandingkan hasil pengamatan Anonimous (2015) di perairan terumbu karang Pulau Salawati dan Pulau Batanta, yang mendapatkan 7 spesies yang secara kuantitatif tidak memperlihatkan perbedaan keragaman spesies yang berarti antar tahun pengamatan tersebut. Walaupun memiliki persentase tutupan karang hidup yang berbeda, lokasi yang dibandingkan memiliki tipe substrat yang relatif sama yang tersusun dari substrat pasir, patahan karang mati (rubble) dan karang mati ditutupi alge (Dead coral with algae). Perbedaan komposisi spesies megabentos antara lokasi yang dibandingkan dapat disebabkan oleh musim, persentase tutupan karang, spesies-speseis karang penyusun terumbu serta variasi tipe substratnya. Arthur (1972) menyatakan bahwa sebaran dan kompleksitas habitat berpengaruh terhadap kelimpahan dan keanekaragaman spesies. Populasi megabentos dapat dipengaruhi oleh tingginya aktivitas manusia pada rataan terumbu seperti rekreasi, memancing, eksplorasi dan pengambilan biota untuk koleksi pribadi (Murray et al., 1990).

Kehadiran spesies-spesies megabentos dengan keanekaragaman yang fluktuatif pada setiap lokasi pengamatan dapat saja disebabkan oleh rendahnya persentase tutupan karang hidup, variasi tipe substrat dan sempitnya rataan terumbu. Jones et al. (1990), menyatakan bahwa perbedaan kekayaan spesies dan keragaman dapat disebabkan oleh perbedaan karakteristik substrat dan sedimen.

Hasil perhitungan nilai kepadatan megabentos menunjukkan bahwa kelompok moluska yang diwakili oleh Drupella cornus memiliki kontribusi yang sangat besar terhadap nilai kepadatan individu yang ditemukan di hampir semua stasiun pengamatan (Tabel1, Tabel 2 dan Tabel 3). Tingginya kepadatan Drupella cornus, erat kaitan dengan kehadiran spesies-spesies karang dari genus Acropora, Pocillophora dan Porites yang merupakan target makanannya, tersebar cukup merata pada hampir semua stasiun. Ini sesuai dengan pernyataan Jimenez et al. (2012) yang menyatakan bahwa ada tidaknya
Drupella pada terumbu karang dipengaruhi oleh ketersediaan makanan.

Nilai kepadatan $D$. cornus yang ditemukan selama pengamatan, umumnya rendah ( $\hat{A} 2$ individu/140m²) dibandingkan dengan hasil pengamatan Ayling \& Ayling (1987) di rataan terumbu karang Ningalon, Australia Barat sebesar 15,7 individu/ $\mathrm{m}^{2}$ yang mampu merusak terumbu karang hingga $85 \%$ dalam waktu 10 tahun. Black \& Johnson (1994) di daerah yang sama, melaporkan bahwa akibat aktivitas makan Drupella menyebabkan pemutihan karang mencapai $22 \%$ dari luasan tutupan karang. Kondisi ini menunjukkan bahwa dengan kepadatan Drupella cornus yang ditemukan pada perairan terumbu karang Pulau Buton dan pulau-pulau kecil lainnya selama 3 tahun pengamatan (2016 - 2018), tidak akan menyebabkan dampak kerusakan atau pemutihan karang yang berarti.

Sedangkan kontribusi terbesar dari kelompok ekinodermata terhadap nilai kepadatan megabentos terdapat di stasiun 1, 3, 4, 6 dan 10, diwakili oleh kehadiran Diadema setosum dan Linkia laevigata. Kehadiran kedua spesies tersebut erat kaitannya dengan kondisi substrat pasir dan karang mati ditutupi alge dan pasir yang sangat dominan pada kelima stasiun tersebut (Anonimus, 2017). Genus Diadema dan Linkia umumnya menyukai mikrohabitat pasir, perairan yang jernih dengan ketersediaan makan yang cukup (De Beer, 1990; Aziz, 1994), dan makanan utama Diadema setosum dan bintang laut lainnya berupa alge bentik yang hidup menempel pada karang mati (Collin \& Arnesson, 1995). Sedangkan rendahnya Diadema pada stasiun lainnya diduga karena rendahnya prefernsi makannya (Aziz, 1994) atau kurangnya kemampuan bersaing dalam menempati habitat (Kekenusa, 1993).

Kehadiran Diadema dalam populasi yang tinggi mengindikasikan karang tidak sehat, dan sebaliknya (Vimono, 2007). Pada kepadatan yang tinggi, D. setosum akan memakan semua organisme, jadi tidak hanya alge dengan demikian akan menghalangi pertumbuhan karang, sedangkan pada kondisi kepadatan yang sangat rendah, alge akan mengambil alih daerah ini dan menghambat pertumbuhan karang. Grazing yang dilakukan oleh $D$. setosum pada kepadatan yang sedang, membersihkan daerah ini atau dapat mengontrol pertumbuhan alge sehingga planula karang dapat menempel dan berkembang, dengan demikian secara tidak langsung membantu memelihara kelangsungan hidup terumbu karang (Sammarco et al., dalam Nybakken, 1992).

Linckia laevigata (bintang biru) merupakan spesies yang tidak berbahaya, pemakan detritus, alge dan lapisan busuk dari biota sessil bentos (Susetiono, 2004; Aziz, 1996; Sloan, 1980), hingga tinggi rendahnya kepadatan Linckia 
laevigata pada suatu perairan erat kaitannya dengan ketersediaan makanan. Interaksi yang terjadi antara terumbu karang dan bintang laut adalah asosiasi mutualisme, dimana Linckia Laevigata mendapatkan makanan dari daerah di sekitar terumbu karang seperti alge, spong, keong, kerang, bulu babi yang telah mati maupun endapan atau materi organik yang terperangkap di terumbu karang. Sebaliknya terumbu karang juga mendapatkan keuntungan dari sifat makan Linckia laevigata sebagai detrivor, sehingga berperan sebagai pembersih atau menjernihkan perairan yang memberikan keuntungan bagi terumbu karang untuk hidup dan bertumbuh dengan baik pada perairan yang jernih.

Acanthaster planci merupakan biota pemakan polip karang hanya ditemukan dalam pada lima stasiun yang berbeda selama pengamatan dengan kepadatan individu yang sangat rendah, dan tidak membahayakan terumbu karang. Endean (1973) menyatakan, pada kepadatan populasi normal, satu individu Acanthaster berkembang menjadi 3 individu dalam waktu 4-5 jam, sedangkan bila terjadi ledakan populasi, spesies ini dapat berkembang menjadi 100 individu hanya dalam 20 menit. Walaupun sebaran dan kepadatan spesies ini sangat rendah dalam tiga tahun pengamatan, namun dampak kehadirannya sangat besar terhadap kerusakan terumbu karang sehingga perlu mendapat perhatian serius dengan melakukan pemantauan secara berkala. Spesies ini dapat saja muncul menjadi individu yang baru hanya dari bagian tubuhnya yang terputus. Sehingga keberadaan jumlah individunya dapat bertambah dengan sangat cepat. Setyastuti (2010) menyatakan, bahwa pada kondisi yang tertekan, Acanthaster planci akan mempercepat proses pematangan gonad dan segera melakukan pemijahan dengan mengeluarkan telur dalam jumlah besar.

Megabentos yang memiliki nilai ekonomis penting seperti Holoturidae, Paniluridae dan Tridacnidae relatif sangat rendah jumlah individunya dan memiliki sebaran yang terbatas, hanya Trochidae yang memiliki sebaran yang luas dengan kepadatan individu yang cukup fluktuatif. Selama pengamatan (2016 - 2018), total nilai kepadatan individu dari megabentos ekonomis penting sangat rendah, dimana total kepadatan Holothurian hanya sebesar 0,03 individu $/ 140 \mathrm{~m}^{2}$ pada pengamatan 2016; 0,06 individu/140 ${ }^{2}$ (2017) dan 0,09 individu $/ 140 \mathrm{~m}^{2}$ (2018); Paniluridae dicatat memiliki nilai kepadatan 0,06 individu/140 $\mathrm{m}^{2}$ pada pengamatan $2016,0,07$ individu/ $140 \mathrm{~m}^{2}$ (2017) dan 0,04 individu/140m² (2018) dan nilai kepadatan Tridacna spp. dicatat hanya sebesar 0,18 individu/ $140 \mathrm{~m}^{2}$ pada pengamatan 2016 , dan terus menurun menjadi 0,14 individu/ $140 \mathrm{~m}^{2}$ (2017) dan 0,13 individu $/ 140 \mathrm{~m}^{2}$ di pengamatan 2018. Sedangkan Trochidae mengalami peningkatan nilai individu dari 0,16 individu $/ 140 \mathrm{~m}^{2}$ pada pengamatan 2016 , menjadi 0,24 individu/140m² (2017) dan 0,31individu/140m² (2018). Nilainilai kepadatan ini mencerminkan rendahnya kepadatan individu spesies ekonomis penting pada setiap stasiun pengamatan, dan mengindikasikan telah terjadi penangkapan yang berlebihan (over fishing). Selain untuk dimakan, spesies-spesies ini mudah ditemukan di pasar lokal, serta memiliki nilai jual yang cukup tinggi di pasaran dan menjadi komoditi ekspor ke manca negara dengan harga tinggi, sehingga menjadi target buruan untuk diekspolitasi. Kondisi seperti ini menyebabkan semakin sulit ditemukannya spesies-spesies tersebut dalam individu yang melimpah dengan sebaran yang sangat terbatas.

Fauna megabentos yang ditemukan dalam tiga tahun pengamatan (2016 - 2018), menunjukkan bahwa tidak ada perbedaan, yang mana jumlah spesies megabentos yang dicatat sebanyak 8 spesies, dan terbagi dalam tiga kelompok utama dengan persebaran spesies antar stasiun relatif sama (Gambar 2). Umumnya fluktuasi kehadiran fauna megabentos yang relatif menonjol hanya terlihat pada stasiun 2, 8 dan 11 yang dipengaruhi oleh hadirnya Acanthaster planci (bintang laut mahkota duri), Panulirus sp. (Lobster), Tridacna spp. (kima) dan Trochus spp. (lola) pada kedua tahun pengamatan sebelumnya (2016 dan 2017), ketiga spesies ini tidak ditemukan. Hadirnya ketiga spesies tersebut pada pengamatan ini (2018), lebih disebabkan oleh tingkah laku dari biota tersebut. Acanthaster planci, Lobster (Panulirus spp.) dan lola (Trochus spp.) merupakan spesies yang mobile dan mampu bergerak pada ekosistem terumbu karang, dan aktif bergerak pada malam hari (nokturnal) sehingga dapat dengan mudah berada atau masuk dalam stasiun transek permanen ataupun tidak. Sedangkan kima (Tridacna spp.) yang ditemukan dalam pengamatan ini umumnya masih berukuran kecil, sedangkan yang berukuran besar telah diambil. Dengan cara hidup yang selalu menempel pada substrat keras, membuat spesies ini sangat mudah untuk ditangkap.

Kepadatan individu megabentos pada setiap stasiun memperlihatkan dinamika yang tinggi, dimana ada spesies yang terus mengalami peningkatan jumlah individunya namun ada juga yang mengalami penurunan individu selama tiga tahun pengamatan 2016 - 2018. Peningkatan jumlah individu megabentos pada stasiun 2, 5, 7, 10, 11 dan 15 dipengaruhi oleh ditemukannya Drupella cornus dalam jumlah yang terus meningkat. Sedangkan pada stasiun 4, 13 dan 14, individu megabentos cenderung menurun. Kondisi ini dipengaruhi oleh menurunnya jumlah individu Diadema setosum dan Linckia laevigata dalam tiga tahun pengamatan. Keberadaan Drupella cornus juga memberikan kontribusi yang cukup besar terhadap fluktuatifnya jumlah individu pada stasiun 1, 3 dan 9, selain Diadema setosum dan Linckia laevigata. Sedangkan pada stasiun lainnya (stasiun 6,9 dan 12), perbedaan kepadatan 
individu antar tahun pengamatan relatif kecil. Semua hasil penelitian tersebut menunjukkan bahwa selain habitat, kondisi lingkungan dan ketersediaan makanan sangat mempengaruhi kehadiran spesies megabentos pada ekosistem terumbu karang.

Walaupun ada terjadi kenaikan atau penurunan kelimpahan individu pada spesies-spesies tertentu di setiap stasiun pada masing-masing tahun pengamatan, namun hasil analisis variasi kelimpahan individu megabentos antara tahun pengamatan, tidak memperlihatkan perbedaan kelimpahan rata-rata individu megabentos yang signifikan antara tahun pengamatan (2016 - 2018). Ini mencerminkan terumbu karang pada setiap stasiun di perairan Pulau Buton dan sekitarnya berada dalam kondisi baik bagi kehadiran fauna megabentos (Gambar 3). Hal ini juga terlihat dengan tingginya nilai kemiripan spesies antar stasiun yang ditemukan > 50\% (Gambar 4), mencerminkan bahwa peluang medapatkan spesies megabentos yang sama pada stasiun yang berbeda sangat besar. Kondisi ini menunjukkan komunitas megabentos pada semua stasiun cenderung memiliki banyak kesamaan antar spesies, begitu juga dengan kondisi substrat yang relatif mirip. Dimana substrat dasar stasiun pengamatan tersusun dari pasir, patahan karang mati, bongkahan karang mati dan karang mati ditutupi alge. Sebaliknya jika memiliki nilai kemiripan yang rendah, maka peluang untuk mendapatkan komposisi spesies yang sama antar stasiun sangat kecil. Kendeigh (1974) menyatakan, suatu komunitas dikatakan sama jika memiliki nilai kesamaan spesies sebesar 50\% atau lebih. Letak lokasi yang berdekatan cenderung memiliki profil dan zonasi substrat dasar relatif mirip, kondisi ini menyebabkan spesies yang sama dapat menempati tempat tersebut secara bersamaan yang pada akhirnya membentuk suatu komposisi spesies yang relatif sama. Ini berhubungan dengan cara hidup fauna megabentos yang umumnya menetap/menempel pada substrat perairan (sessil) dan memiliki pergerakan yang relatif lambat. Dengan kata lain, tipe substrat perairan dan kebiasaan hidup megabentos tersebut merupakan satu kesatuan sistem yang dapat memengaruhi tingkat kemiripan spesies antar stasiun. Hal ini sesuai dengan pernyataan Islami \& Mudjiono (2009), yang menyatakan bahwa tekstur sedimen atau substrat dasar merupakan salah satu faktor ekologis utama yang mempengaruhi kelimpahan dan penyebaran makrozoobenthos.

Suatu organisme melakukan asosiasi kemungkinan karena ingin mendapatkan keuntungan dari asosiasi yang dilakukannya. Ada yang saling menguntungkan (mutualisme), saling merugikan (parasitisme), atau yang satu diuntungkan sedangkan yang lain tidak mendapatkan keuntungan (komensalisme) dari asosiasinya terhadap simbionnya, dimana penyebab utama terjadinya interaksi antar biota berhubungan dengan ketersediaan makanan.
Hasil analisis Spearman, menunjukkan nilai asosiasi positif yang tertinggi terdapat antara lobster (Panulirus spp.) dengan spesies-spesies karang dari famili Mussidae $(0,61)$ dan Faviidae $(0,50)$. Tingginya nilai ini merupakan hal unik yang ditemukan dalam pengamatan ini. Bila dilihat dari cara hidup lobster yang menyukai perairan bersubstrat pasir berbatu dan biasanya berkelompok di dalam lubanglubang batu (Trijoko, 1994), maka kehadiran lobster pada spesies karang tersebut apakah hanya karena adanya makanan atau untuk berlindung, perlu diamati lebih mendalam untuk mengetahui apa ada hubungan yang spesifik yang saling menguntungkan antara lobster dan spesies karang tersebut. Kedua kelompok biota ini selalu ditemukan hidup pada perairan yang jernih dengan substrat pasir.

Nilai korelasi negatif tertinggi terdapat antara Diadema setosum dan spesies karang dari famili poritas $(-0,58)$. Nilai ini mencerminkan bahwa spesies Diadema setosum tidak terlihat atau sangat sedikit individunya pada rataan terumbu karang yang didominasi oleh famili Poritidae berukuran besar, bentuk morfologi bulat (helm shape) polip berukuran kecil (Luthfi et al., 2015) yang ditemukan hampir pada setiap stasiun. Selain bentuk pertumbuhan yang massif dan berukuran besar, spesies-spesies karang ini hidup pada perairan yang terbuka, berombak, berarus, air yang jernih maupun yang keruh. Pada stasiun-stasiun yang terbuka, berarus dan berombak (stasiun 2, 5, 6, 7, 8, 9, 10, 11, 12, dan 14), pertumbuhan karang umumnya didominasi oleh famili Poritidae dan pada stasiun-stasiun ini, kehadiran Diadema setosum sangat sedikit dan bahkan tidak ditemukan. Sebaliknya Diadema setosum hidup dengan baik pada perairan yang jernih, berpasir, karang mati dengan pertumbuhan karang yang umumnya tidak tinggi atau datar seperti bentuk pertumbuhan dari famili Fungidae, sehingga mempermudah keberadaan spesies tersebut. Kehadiran genus diadema pada rataan terumbu karang lebih disebabkan oleh tersedianya alge sebagai makanan utamanya (Collin \& Arnesson, 1995).

Nilai korelasi posisitf yang signifikan antara Drupella cornus dan famili Acroporidae adalah sebesar 0,57, yang memperlihatkan begitu kuat hubungan antara famili Acroporidae sebagai target makanan dari Drupella cornus. Banyaknya spesies karang dari genus Acroporide yang hadir cukup merata pada semua stasiun, turut memengaruhi sebaran spesies Drupella cornus yang ditemukan hadir pada semua stasiun dengan nilai frekuensi kehadiran 100\% dengan kelimpahan individu yang tinggi.

Sedangkan nilai korelasi positif sebesar 0,48 terdapat antara Tridacna spp. dan spesies-spesies karang dari famili Faviidae. Semua spesies Tridacna spp. yang ditemukan selama pengamatan umum berukuran kecil Ầ15 cm, dan hidup menempal pada celah-celah karang, ada juga yang membenamkan diri dalam bongkahan karang mati ataupun 
karang hidup. Tridacna tumbuh dan berkembang dengan baik di ekosistem terumbu karang, pada perairan yang jernih. Hal ini berhubungan dengan cara makannya yang menyaring makanan dari perairan sekitar (filter feeder). Umumnya kehadiran genus Tridacna pada ekosistem terumbu karang berkaitan dengan substrat keras dan zooxanthellae. Keberadaan Tridacna spp. yang ditemukan hidup berdekatan dengan spesies-spesies karang dari famili Faviidae mungkin berkaitan dengan ketersedian makanan dan substrat serta keberadaan zooxanthellae yang membantu genus Tridacna untuk mencukupi kebutuhan makanannya. Coffroth \& Santos (2005) menyebutkan bahwa infeksi dari zooxanthellae terhadap inangnya dapat terjadi melalui dua kondisi yang disebut close system (sistem tertutup) yaitu suatu kondisi dimana terjadinya hubungan inang-simbion yang terjadi melalui infeksi sejak planulanya (bersifat endemik) serta open system (sistem terbuka) yaitu suatu kondisi ditemukannya ragam clade pada suatu inang berasal dari infeksinya dengan lingkungan sekitar sebagaimana dikemukakan oleh Pochon et al. (2001). Purnomo (2011) juga menyatakan bahwa selain genus Acropora, variasi keragaman zooxanthellae pada genus Favites dari famili Faviidae relatif sama dengan genus Tridacna.

\section{KESIMPULAN}

Fauna megabentos yang ditemukan di terumbu karang perairan Pulau Buton dan pulau-pulau kecil di sekitarnya sebanyak 8 spesies. Kelompok ekhinodermata mencakup jumlah spesies terbanyak (4 spesies), diikuti kelompok moluska (3 spesies). Kehadiran Drupella cornus pada semua stasiun pengamatan berkaitan erat dengan meratanya persebaran spesies-spesies karang (famili Acroporidae) sebagai sumber makanannya. Drupella cornus (moluska), Diadema setosum dan Linkia laevigata (ekinodermata) memiliki kontribusi yang besar terhadap tinggi rendahya nilai kepadatan individu megabentos. Teripang (Holothurian), lobster (Panulirus sp.) dan kima (Tridacna spp.) memiliki sebaran yang relatif terbatas dengan kelimpahan individu yang rendah, mengindikasikan bahwa telah terjadi penangkapan yang berlebihan (over fishing). Tidak ada perbedaan kepadatan rata-rata individu megabentos yang signifikan antar tahun pengamatan (2016 - 2018). Tingginya nilai kemiripan (similarity) spesies megabentos antar stasiun (>50\%), disebabkan oleh kemiripan tipe substrat dan habitat.

\section{PERSANTUNAN}

Penulis mengucapkan terima kasih kepada Tri Aryono Hadi M.Sc. selaku koordinator Coremap-CTI III (2015 2019) yang telah mendukung kegiatan Monitoring Kesehatan Terumbu Karang dan Ekosistem Terkait di Kepulauan Buton, Sulawesi Tenggara. Ucapan terima kasih juga disampaikan kepada Hadiyanto MSc. dan
Wayan Eka Darmawan MSI yang telah membantu mengolah data serta rekan-rekan peneliti dan teknisi atas kerja sama yang baik selama penelitian di lapangan.

\section{DAFTAR PUSTAKA}

Abbott, R.T., \& Dance, P. (1990). Compendium of Seashell (p. 411). Australia: Crawford House Press.

Anonimous. (2015). Monitoring kesehatan terumbu karang dan ekosistem terkait di Pulau Salawati dan Pulau Batanta, Kabupaten Radja Ampat, Papua Barat. Program Coremap-CTI. Pusat Penelitian Oseanografi-LIPI, 85 hal.

Anonimous. (2017). Monitoring kesehatan terumbu karang dan ekosistem terkait di perairan Ternate, Provinsi Maluku Utara. Program Coremap-CTI. Pusat Penelitian Oseanografi-LIPI, 90 hal.

Anonimous. (2017). Monitoring kesehatan terumbu karang dan ekosistem terkait di Kepulauan Wakatobi, Provinsi Sulawesi Tenggara. Program Coremap-CTI. Pusat Penelitian Oseanografi-LIPI, 94 hal.

Anonimous. (2017). Monitoring kesehatan terumbu karang dan ekosistem terkait di Kepulauan Pulau Buton, Sulawesi Tenggara. Program Coremap-CTI. Pusat Penelitian Oseanografi-LIPI, 95 hal.

Arthur, M.R.H. (1972). Geographycal ecology pattern in the distribution species (p. 287). New York: Harper \& Row. Publish.

Ayling, A.M., \& Ayling, A.L. (1987). Ningaloo Marine Park: preliminary fish density assessment and habitat survey, with information on coral damage due to Drupella cornusgrazing, Report, Department of Conservation and Land Management.

Aziz, A. (1994). Tingkah laku bulu babi di padang lamun. Oseana. 14(4), 35-43.

Aziz, A. (1996). Makanan dan cara makan berbagai jenis bintang laut. Oseana. 21(3), 13-22.

Birkeland, C. (1989). The influence of echinoderms on coralreef communities: In Jangoux, M. \& J.M. Lawrence (eds.). Echinoderm Studies. 3, 1-77.

Black, R., \& Johnson, M.S. (1994). Growth Rates in Outbreak Population of The Corallivorous Gastropoda (Drupella cornus) (Roding 1798) at Ningaloo Reef, Western Australia. Coral reefs. 13, 145-150. https:// doi.org/10.1007/BF00301190. 
Calumpong, H.P. (1992). The Giant Clam: An Ocean Culture Manual (p. 68). AClAR Monograph No. 16. Canberra: ACIAR.

Cappenberg, H.A.W. (2014). Struktur komunitas megabentos di Perairan Pangkajene Kepulauan Kabupaten Pangkep, Sulawesi Selatan. Zoo Indonesia (Jurnal Fauna Tropika). 23(2), 57-67.

Clark, A.M., \& Rowe, F.W.E. (1971). Monograph of shallow-water Indo-west Pasific Echino- derms (p. 238). London: Trustees of the British Museum (Nat. Hist.).

Collin, P.L., \& Arnesson, C. (1995). Tropical Pasific Invertebrates (p. 209). California: Coral Reef Press.

Coffroth, M.A., \& Santos, S.R. (2005). Genetic diversity of symbiotic dinoûagellates in the genus Symbiodinium. Protist. 156(1), 19-34. doi: 10.1016/ j.protis.2005.02.004.

Dance, P. (1976). The collector's encyclopedia of shell ( $\mathrm{p}$. 288). New Jersey: Cartwell Book Inc.

De Beer, M. (1990). Distribution patterns of regular sea urchins (Echinodermata: Echinnoides) cross the Spermonde shelf, SW Sulawesi (Indonesia). In De Ridder, Dubois, Lahaye \& Jangoux (Eds.). Proceedings of the second European conference on echinoderms Brussels, Belgium, 18 - 21 September 1989 (p.165169). Leiden: National Museum of National History.

Edward. (2010). Pelestarian Lola (Trochus niloticus) Melalui Penebaran dia alam. Laporan Kegiatan Insentif Dikti tahun 2010 UPT Loka Konservasi Biota Laut Tual. 45 hal.

Endean, R. (1973). Population explosions of Acanthaster planci and associated destruction of hermatypic corals in the Indo-West Pacific region. In Jones, O.A. and R. Endean (Eds.), Biology and geology of coral reef (pp. 389 - 438). New York: Academic Press. https://doi.org/ 10.1016/B978-0-12-395526-5.50020-1

Gomez, E.D., \& Yap, H.T. (1988). Monitoring Reef Condition. In R.A. Kenchington, R.A. \& B.E.T. Hudson (Eds). Coral Reef Management Handbook (p. 171). Jakarta: UNESCO Publisher.

Hartati, R., Widianingsih., \& Pringgenies, D. (2005). Teknologi Penyediaan Pakan Bagi Teripang Putih (Holothuria scabra) (38 hal). Semarang: Laporan Kegiatan Penelitian Hibah Bersaing, Universitas Diponegoro Semarang. http://eprints.undip.ac.id/ 22492/1/419-ki-fpik-06-a.pdf
Islami, M.M., \& Mudjiono. (2009). Komunitas moluska di perairan Teluk Ambon, Provinsi Maluku. Oseanologi dan Limnologi di Indonesia. 35(3), 353-368. https:// www.researchgate.net/publication/274066706_ Komunitas_moluska_di_Perairan_Teluk_Ambon_ Provinsi_Maluku/link/5595fd8908ae21086d208553/ download

Jimenez, H., Dumas, P., Ponton, D., \& Ferraris, J. (2012). Predicting Invertebrate Assemblage Composition from Harvesting Pressure and Environmental Characteristics on Tropical Reef Flats. Coral Reefs. 31(1), 89-100. DOI: 10.1007/s00338-011-0820-9

Jones, G.P., Ferrell, D.J., \& Sale, P.F. (1990). Spatial pattern in the abundance and structure of mollusc popullations in the soft sediments of a coral reef lagoon. Marine Ecology Progress Series. 62, 109 - 120.

Kekenusa, J. S. (1993). Pola penyebaran, keanekaragaman dan asosiasi antara species teripang di pesisir pantai barat Pulau Nain, Sulawesi Utara. Jurnal Fakultas Perikanan UNSRAT. 11(4), 11-17.

Kendeigh, S.C. (1974). Ecology with special referenceto animals and man (p. 474). New Jersey: Prentice-Hall.

Luthfi, O.M., Guntur., \& Nugraha, N.A. (2015). Identifikasi morfologi karang masive Porites di perairan Laut Selatan Jawa. Seminar Nasional Perikanan dan Kelautan VI (pp. 545 - 549). Malang, Indonesia: Fakultas Perikanan dan Ilmu Kelautan, Universitas Brawijaya. https://www.researchgate.net/publication/

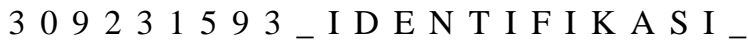
MORFOLOGI_KARANG_MASSIVE_ PORITES_DI_PERAIRAN_LAUT_SELAT AN_JAWA/link/5806396b08ae5ad188162e04/ download

Manuputty, A.E.W., Giyanto, Winardi, Suharti, A.R., \& Djuwaria. (2006). Manual monitoring kesehatan karang (Reef health monitoring). Jakarta: LIPI. http:/ /coremap.or.id/downloads/Manual-RHM.pdf

Murray, S.N., Denis, T.G., Kido, J.S., \& Smith, J.R. (1990). Human visitation and the frequency and potential effects of collecting on rocky intertidal populations in southern California marine reserves. California Cooperative Oceanic Fisheries Investigation Reports. 40, 100-106. http://calcofi.org/publications/ calcofireports/v40/Vol_40_Murray_etal.pdf

Nybakken, J.W. (1992). Biologi laut, suatu pendekatan ekologi (p. 496). Jakarta: PT. Gramedia Pustaka Utama. 
Pochon, X., Pawlowski, J., Zaninetti, L., \& Rowan, R. (2001). High genetic diversity and relative specificity among Symbiodinium-like endosymbiotic dinoflagellates in soritid foraminiferans. Marine Biology. 139, 1069-1078. https://doi.org/10.1007/s002270100674

Purnomo, P.W. (2011). Keragaman genetik zooxanthellae dari beberapa sumber inang di perairan terumbu karang Pulau Bokor, Jepara. Jurnal Saintek Perikanan. 7(1), 39 - 45. https://pdfs.semanticscholar.org/2483/ bcff6b3af7b1b990283485740c22c1a7eb1e.pdf

Poutiers, J. (1998). The Living Marine Resources of The Western Central Pasific. Vol.1: Seaweeds, corals, bivalves and gastropods. FAO of The United Nation. $686 \mathrm{pp}$.

Pramudji. (2017). Laporan Monitoring kesehatan terumbu karang dan ekosistem terkait di Kawasan Pesisir Kendari, Provinsi Sulawesi Tenggara (95 hal). Jakarta: Pusat Penelitian Oseanografi-LIPI.

R Core Development Team. (2018). R: A language and environment for statistical computing R Foundation for statistical computing, Vienna, Austria. http:// www.R-project.org/

Setyastuti, A. (2010). Tinjauan ledakan populasi dari bintang laut mahkota duri, Acanthaster planci. Oseana. XXXV, (3), 1-6.

Sloan, N.A. (1980). Aspects of feeding biology of asteroidean (p. 57-124). Oceanogr. Mar. Biol. Ann. Rev. 18.
Susetiono. (2004). Fauna padang lamun. Jakarta: P2OLIPI.

Setyono, D.E.D. (2006). Budidaya pembesaran udang karang (Panulirus spp.). Oseana. 31(4), 39-48.

Trijoko. (1994). Sex rasio dan masa bertelur udang karang (Panulirus spp.) di perairan Pangandaran, Jawa Barat (14 hal). Makalah dipresentasikan pada Seminar Nasional Biologi Menuju Milenium III. Yogyakarta, Indonesia: Fakultas Biologi, Universitas Gajah Mada.

Veron, J. (1993). Corals of Ausralia and the Indo-Pasific (656 pp). Australia: The Australian Institute of Marine Science.

Veron, J.E.N. (1993) A biogeographic database of hermatypic corals: species of the central

Indo-Pacific, genera of the world. Aust. Inst. Mar. Sci Monogr. Ser. 9.

Vimono, I.B. (2007). Sekilas mengenai landak laut. Oseana. XXXII, (3), 37-46. http://oseanografi.lipi.go.id/ dokumen/oseana_xxxii(3)37-46.pdf

Warwick, R.M., \& K.R. Clarke. (2001). Change In Marine Communities: An Approach to Statistical Analysis And Interpretation (p. 169). UK: PRIMER-E Limited.

Wilson, B. (1993). Australian Marine Shells (p. 406). Vol. I. Western Australia: Odyssey Publishing. 